\title{
The Conservation of Cultural Heritage Areas of Film City in Kota Lama of Semarang
}

\author{
Sri Wastiwi Setiawati, Titus Soepono Adji, Widhi Nugroho, Iwan Darmawan, Moh. \\ Rusnoto Susanto, Adri Yandi \\ \{ tiwi.ws@gmail.com¹, tusjik123@gmail.com²,widhinugroho1980@gmail.com³, \\ tatasuaraindonesia@gmail.com ${ }^{4}$, rusnoto@ustjogja.ac.id ${ }^{5}$, sluncko61@yahoo.com ${ }^{6}$ \} \\ Jurusan Televisi, Institut Seni Indonesia Surakarta, Surakarta-Indonesia ${ }^{1,2,3}$, Jurusan Televisi \\ Institut Kesenian Jakarta, Jakarta-Indonesia ${ }^{4}$, Program Studi Pendidikan Seni Rupa, Universitas \\ Sarjanawiyata Tamansiswa, Yogyakarta-Indonesia ${ }^{5}$, Jurusan Televisi, Institut Seni Budaya Indonesia, \\ Padang Panjang-Indonesia ${ }^{6}$
}

\begin{abstract}
The objective of this study is (1) to obtain the potential data of Kota Lama of Semarang, as a Cultural Heritage area of a Film City and (2) to produce a map of the potential of Kota Lama, both aesthetic and artistic potentials through a visual potential that might be used as a shooting location in Kota Lama. As a qualitative research, the approach used is a verification that has an inductive approach toward the entire research processes. The study explored qualitatively and verificatively, along with data from area managers, and filmmakers who made movies in Kota Lama of Semarang. As the data show, around 20 films use Kota Lama Area as a shooting location, and most of the historical genre films are colossal in nature. In addition to the visual potential of the region, the research results seek to maximize the role of Kota Lama area as a center for film production in Indonesia, as it is much-needed to map out problems and obstacles, regulation and licensing, technical support for film production, public supporting facilities, and warehousing of a workshop for storing and cultivating artistic sets. The absence of regulations precipitates the violation of regulations and procedures for the film production in Kota Lama of Semarang as a Cultural Heritage area.
\end{abstract}

Keywords: Kota Lama, Semarang, Film City, Regulation, Conservation

\section{Introduction}

Kota Lama of Semarang is an area of approximately 31 hectares. In the seventeenth century until the beginning of the twentieth century, this area was the center of Semarang as well as the Dutch East Indies government, and it is not surprising that the region has many colonial buildings in a wide variety of styles ranging from Gothic, Art Nuvo, Art Deco, to Indies. Like other cities, Semarang is fortunate to have old colonial-era urban areas because its area is quite intact, compared to other cities that damage the city's landscape because many of its old buildings were demolished and replaced by modern buildings. The integrity and authenticity of this area is widely used as a setting in the production of national films, especially those with a historical background. Gie's film, Soegija, or Soekarno is an example of a film that uses Kota Lama as a film shooting location. The potential of local human resources is less cultivated. Besides, the filming was produced without any supervision, so that many filming activities were undertaken haphazardly that in turn damaged the location, even 
though some buildings in Kota Lama were legally designated as Cultural Heritage through Permanbudpar no.57 / 2010 whereas each activity has the potential to cause damages that can be threatened with criminal sanctions.

On the other hand, Kota Lama area is often used for various national film productions that actually give a considerable domino effect, among others, for example, the potential benefits in several service sectors such as hospitality, catering, transportation, local arts, etc.

In addition, other potentials have not been available in Semarang areas such as filming equipment rental or film production and the availability of production workshops directly related to production such as artistic arrangement, costumes, artists' makeup, and so forth. Thus, the use of Kota Lama as the location of the National Film production can trigger the movement of the creative sectors. In terms of the city branding, optimizing the potential of Kota Lama region as a National Film production center is expected to promote Kota Lama area as one of the Semarang's tourist destinations. In general, promoting Semarang as one of the creative tourism cities at the National level is of paramount importance.

The objective of this study is to produce a map of the potential of the Old City, both aesthetic and artistic potentials, which are demonstrated through a visual platform that might be used as a shooting location in the Old City.

Cultural heritage buildings according to the Indonesian Heritage Conservation Agency (BPPI), as quoted in the Heritage Education Training Module, include the Building Heritage. Building heritage is buildings that for certain reasons are considered important by a group of people. There are many reasons why the building in question is considered important. For example, the building is very old, rare (the only one), unique, and or used as a marker of an area or city. As a master piece work, the building has important values in terms of architecture, artistic and historical values. The historical value of a building is shown, for example, through functions of the building, namely as a place where historical events are held or related to historical figures.

Kota Lama area along with the buildings has a high historical value. For this reason, conservation efforts in this regard are important. Borrowing a quote from the Indonesian Heritage Preservation Charter which that was released in 2003, one of the concerns in the heritage conservation includes Indonesia's priceless heritage that has been polluted, damaged, destroyed, lost, or threatened by its sustainability due to ignorance, disability, and mismanagement for short-term benefits and interests of certain groups.

In his article Kota (Pusaka) Sebagai Living Museum, reminds that the complexity and empirical experience of conservation activities deal with the future challenges on how preservation of cultural heritage is set to strengthen typical urban experiences without having to sacrifice the existing conditions of the authenticity of architectural, communal details and other urban features [1]. Films provide opportunities to strengthen urban experience, not only for the people of Semarang City, but also for the film community related to the cultural discourse in Indonesia.

In this article he explains that the history of the establishment of Kota Lama area was based on the VOC from Semarang, the Mataram kingdom in 1678, and its development in modern times [2]. The important point in this article is the interview with Murtomo about variations in building styles in the region, and further developments further reaffirm the presence of colors originating from other parts of Europe. The architecture of Kota Lama of Semarang, as it still looks now, is more impressive as a blend of various traditions and styles of Europe that might get a little local touch.

A wide variety of buildings established in Kota Lamacan be an alternative wealth setting in film productions. Another article, written by [3], and it confirms the unique characteristics 
of Kota Lama as a colonial city area. This character has a great potential develop, among others, in the field of tourism. In this article Sukawi applies 3 nodes in Kota Lama area mainly considered to be potentials as tourist areas, namely the node Berok, node Blenduk and node Tawang. The Blenduk and Tawang have potentially been tourist points in Kota Lama region.

As this research indicates, the architectural and tourism side is processed more prominently. However, the film industry sector has not adequately been processed to explore its potential. Since Semarang was fully handed over to the VOC in 1705, it built a new colony area to replace Jepara. Starting from a small fortress, then a port, and finally manifesting itself as a modern fortified city area equipped with important residential buildings, offices, government buildings, and other public facilities, Semarang still exists today through the Nilmij building, Culture Mascapij, Higea, editor in chief of Locomotief, Colonial Bank and Javasche Bank, Oei Tiong Ham Concern, Societet and others, which are now called an Old City. In the era of independence, buildings which were previously controlled by the Dutch East Indies Company were nationalized, some of which are currently controlled by SOEs, and some others are used for several government and military agencies [4].

Amid visually apprehensive conditions, Kota Lamais a very attractive area that has many authentic ancient buildings, and it was a setting for urban areas in the past. Dozens of historical-themed films were produced in this region including Ca Bau Kan (2001), Gie (2005), Lawang Sewu (2007), Kala (2007), The Photograph (2007), Ayat-Ayat Cinta (2008), May (2008), Punk In Love (2009), Rumah Maeda (2009), Merah Putih (2009), Darah Garuda (2010), LaskarPemimpi (2010), Hati Merdeka (2011) Tanda Tanya (2011), Di Bawah Lindungan Ka'bah (2011), Soegija (2012), Sang Kyai (2013), Soekarno: Indonesia Merdeka (2013), and Guru Bangsa (2015). The design of a film can create a sense of place. The atmospheric qualities of the sets, locations, and environments are essential in establishing a mood and projecting an emotional feeling about the world surrounding the film. The director of photo-graphy can bring atmosphere to a set by applying color gels, through choice of lenses, lighting, and with smoke and diffusion, but the production design must provide the physical elements [5].

Kota Lama is a main consideration for making movies because it is rich in colonial architectural works. As a need for authentic and specific artistic sets, the movie-making in this region has a historical basis. This is in the realm of film production, according to [5] and he explains how the producer treatment is applied in building production planning for a film production. In this book several chapters are quite relevant to this research including the design of a film can create a sense of place. The atmospheric qualities of the sets, locations, and environments are essential in establishing a mood and projecting emotional feelings about the world surrounding the film. The director of photo graphy can bring atmosphere to set colors, through choice of lenses, lighting, and with smoke and diffusion, but the production design must provide the physical elements.

Referring to the insights of Himawan Pratista in the book Memahami Film [Understanding Films] and the concepts of David Letwin and friends in the book The Architecture of Drama, setting is an integral part of the whole settings with all its properties. In this case, properties are all immovable objects such as furniture, doors, windows, chairs, lights, trees, and so on. The settings in a film are generally made as real as possible in the context of the story. Perfect settings in principle are authentic settings. The setting must be able to convince the audience if the film really appears to occur at the location and time according to the context of the film's story. If the actual use of the location is not possible or does not exist anymore, usually the filmmaker searches for a similar location or can design a rebuild that is close to the original profile. 
Kota Lama of Semarang is a heritage area that is authentic and close to the original profile if you look at past settings. As a quite promising and convincing area in terms of aesthetics, it necessary to use a managerial technical approach toward sets / locations in Kota Lama area that filmmakers (producers) undertake to succeed a film production. The prospective location not only appropriates artistic demands of the director, but also its budgetary and logistical framework of production. For example, a perfect location according to the directors and art directors is a day to reduce to unacceptable level. A perfect location from a logistical stand point might be imposible from the art director of extensive remodeling point of view outside the production schedule or budget is required [6].

Settings are closely related to budgets or technical matters that accompany them. This is what underlies the producer to consider the choice of location (setting) which is not only based on the decisions of the director or the artistic artist per se. In this case, the technical needs in the settings refer to the scope of the location. If we review further by referring to the words of Bastian Cleve, the aesthetic setting is a choice of the director or the artistic director, but the authority of the filmmaker (the producer) in determining the setting may refer to technical issues such as budget, equipment rent, location permit, duration of shooting, complete infrastructure and other things that affect the smooth running of the shooting. Like the opinion of Bastian Cleve, Kota Lama area of Semarang has a friendly type for film production, among others, indicated by the proximity of the city center, so that it is close to many hotels as a means of accommodation and central government for licensing matters.

In addition to written references in the form of books and journals, several visual references from films have been produced in the Old City, Semarang such as Film Gie (2005), raising the true story of the life of Soe Hok Gie, a student activist from the University of Indonesia. This film has a historical background in 1966. It tells about the story of Soe Hok Gie of a Chinese descent who is strongly concerned about social and political issues. The cost of producing films reaches tens of billions of rupiah involving thousands of players including extras. The filming location is mostly in Semarang, even almost $80 \%$ of the filming is made in Semarang City. Filming locations include Kampung Melayu, Chinatown, Undip Campus and Kota Lama of Semarang. Soeprapto Street (the Blenduk church area), Kepodang road and Berok Bridge area. They become the locations of a film to make up the atmosphere of demonstration in the UI Jakarta Campus area.
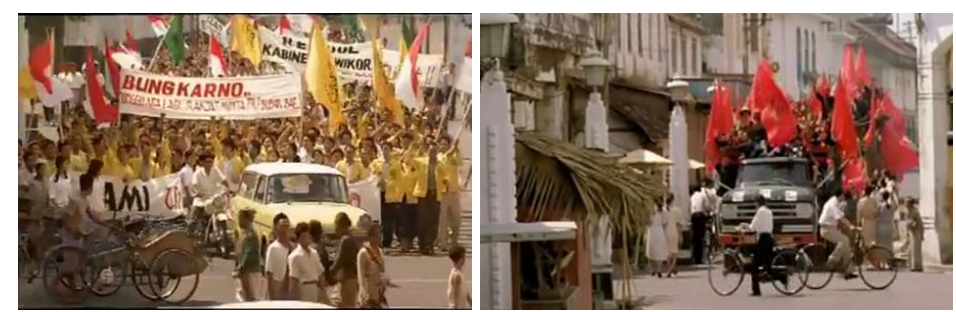

Fig. 1. The setting of Gie film in Kota Lama area of Semarang (Sourse: The capture of film Gie)

Kala (2007) is a movie that was produced in Kota Lama of Semarang. The movie is actually set in a city in the middle of nowhere. Nevertheless, its setting in Kota Lamahas succeeded in establishing the alienation of locations, even though the movie tells about stories with Indonesian actors speaking Indonesian language. The management of this movie production has attracted attention that Indonesia has a "different" sense in making movies is a fictional movie produced in 2012, and it represents the phenomenon of social tensions in society related to inter-religious conflicts which at the time the movie production became a 
fairly widespread phenomenon. Kota Lama area is a story setting that really exists as the city of Semarang. In the movie, Kota Lamarepresents a depressing picture of the city, and living alongside religious conflicts among its pluralistic communities.

\section{Method}

This qualitative research used a verification approach commonly called a qualitative verification research that has an inductive approach to the entire research processes [7]. In this study, the data collection is the most important thing to do. This approach is considered appropriate because no studies have led to the development of the potential of Kota Lama as the center of the film industry, so that there are no theoretical references amid abundant collected data. Conducted in Semarang City, this study took the form of potential development in the location of Kota Lama and its surroundings, stakeholder and BPK2L interviews, Jakarta and surrounding areas, in the form of interviews with film industry stakeholders, and field observations at Studio Persari, Ciganjur, South Jakarta, Kota Tua Jakarta, Yogyakarta, and interviews with stakeholders in the film industry.

\section{Discussion}

Kota Lama of Semarang is in an area of 31 hectares. The diversity of buildings in this area is widely used by filmmakers as filming locations with past settings. From the presentation of several films that uses Kota Lama of Semarang, several locations are potentially used as shooting locations. In addition, the existence of Kota Lama of Semarang is supported by several potential locations in Semarang and its surroundings.

\subsection{The Visual Potential of Old City of Semarang within a Cinemtographic Frame}

1. Jalan Kepodang or Chicken Market, it is a road in the form of a crossroad with several unique potentials, a fairly wide paving road, two large buildings that are cornered into a corridor and give the impression of magnificence, and the ruins of buildings covered in tree roots create an impression of being an ancient and abandoned city.

2. Branjang Street, the Branjang and Garuda Road Area is a junction with the building in a fairly iconic skewer position. This T-junction is wide enough to give a colossal impression.

3. Blenduk Church, Blenduk Church Area is the area of Letjend Soeprapto road that integrates the Srigunting park and unique large buildings nearby. This area is the center of Kota Lama of Semarang

4. Berok Bridge, it is the main corridor to Kota Lama of Semarang. This area is a junction with the largest size of road, and has a background of magnificent buildings. Scene demonstrations and mass mobilization often occur at this location. The visual potential of Kota Lama of Semarang is uncovered by reviewing several films produced there including fictional films of Tanda Tanya, Kala, The Photograph, and films with historical genres including Gie, Rumah Maeda, Soegija, Sang Kyai, Soekarno and Guru Bangs. A number of films are followed by identifying the shooting location in Kota Lama of Semarang. Observations in the field are undertaken taking photos of places that have been used as film settings. The results of several photos in shooting locations are compared to identify 
the actual locations and the dressing in the shooting locations. As a filming location, Kota Lama of Semarang is supported by surrounding areas in Kota Lama to support visual potentials in film production. The locations of the supporters include Kampung Melayu Area, Chinatown, Lawang Sewu, Ambarawa Station and Fort Willem, Agro Tlogo Tuntang and so on.

5. Like Kampung Melayu, Semarang's Chinatown is also bordered to the South of Kota Lama. The history of this region originated from the ethnic Chinese rebellion in 1740 against the VOC that extended to Central Java. Due to this incident, the VOC government moved the Chinese ethnics to an area near Kota Lama so that it was easily to monitor them. At present, the area is inhabited for generations, and many typical Chinese buildings are often used as film production settings.

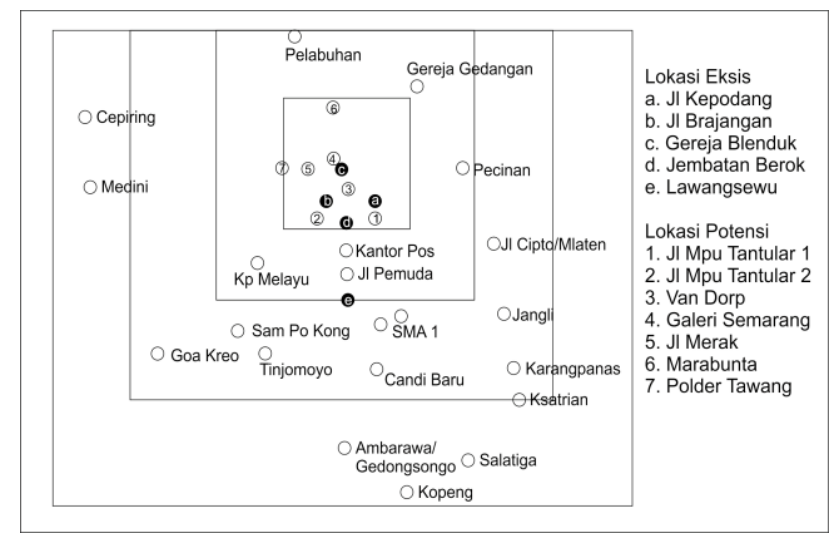

Fig. 2. Visual Potential Map of Kota Lama

Branjang and Garuda road areas are a junction with the building in a fairly iconic skewer position. This T-junction is wide enough to give a colossal impression. The Blenduk Church area that integrates with the Srigunting park has unique large buildings around it. This area is the center of Kota Lama of Semarang. While the Berok Bridge Area is the main corridor to Kota Lama of Semarang. This area is a junction area with the largest size of road, and has a background of magnificent buildings.

To regulate the load capacity of Kota Lama, the division of roles between Kota Lama and other locations around Semarang have a typical thematic type. Thus, this division of roles has taken place including several films using the Kampung Melayu area (Layur Mosque), Semarang Chinatown, Lawangsewu, or Karangpanas Church in the Temple area. 


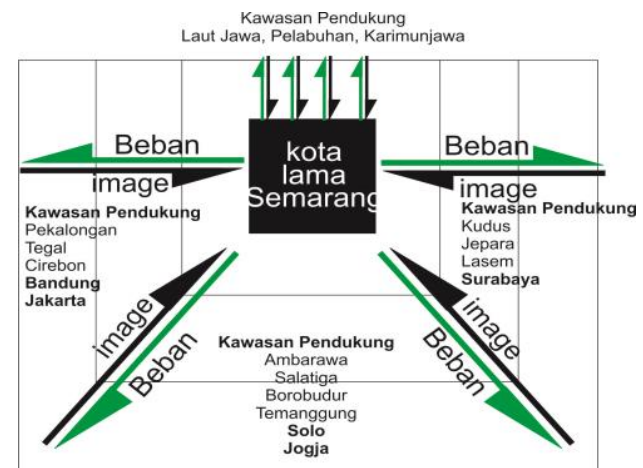

Fig. 3. Supported Areas in Kota Lama of Semarang

The scheme shows that Kota Lama of Semarang will have limitations in accommodating all film production activities, especially if this area is later designated as a film production area. This burden will be very heavy considering Kota Lama also acts as a tourist destination, business area and other urban functions, as well as conservation areas.

\subsection{The Potential of Kota Lama of Semarang as a Film City}

Kota Lama of Semarang along with its wealth of buildings attracts filmmakers to make films there. The building's wealth deals with geometric elements of architecture such as curves, straight lines, squares and angles that made the director Joko Anwar (Jakarta, July 15, 2016) chose Kota Lama as the location for Kala's film production. This is a vital consideration in choosing a location, because the geometry in the screen / film determines the story telling. Stories and artistic interests are taken into consideration when choosing Kota Lama of Semarang as a shooting location. The same thing was conveyed by Hanung Bramantyo that Kota Lama of Semarang is interesting because the building is artistic, so that it would be made a modern setting.

Hanung Bramantyo (Jakarta, July 29, 2016) articulates that the city of Semarang is one of the cities that has the potential to move the city of Jakarta as the center of the film industry, because Jakarta has become too crowded and jammed. In addition, transportation modes in Semarang are supported by air, land and sea transportation, all of which are in Semarang, and this is the capital for a film industry center. This is what distinguishes Semarang from other cities, for example, Yogyakarta. Semarang City also has diverse natural resources, such as mountains, old cities, modern cities, and train museums near the cold places in Salatiga.

Tia Hasibuan (Jakarta, July 15, 2016) adds that to become a film city, the problem of food, lodging and hospitals in Semarang is quite adequate. From Kota Lama, it is quite easy to reach, so that the time can also be quite effective, because the distance is not too far away. But there are two things that are not yet available and become an obstacle when making films in Kota Lama, namely, the toilet, because old buildings and many empty buildings are not used in Kota Lama, so that toilets are not available. The second is a parking lot, and it is important for many cars, so that there is a need for parking. Agus Santoso (Jakarta, July 15, 2016) argues that besides toilets and parking lots, things that must be available are warehouses that can be rented for the needs of making films and storing artistic needs, and large buildings/warehouses are good for studios when people need studio green screens. This is actually easy because many large and empty buildings can be utilized, but the problem is that an empty building has 
no owner. The other needs are production support, which is currently filming equipment from Yogyakarta and Jakarta.

When Kota Lama becomes the City of Film, a clear regulation is much-needed. So far, licensing for the use of Kota Lama for filming locations, the government is limited to providing internal recommendations between government agencies. Recommendations do not reach facilities within the scope of policies related to the film production (An interview with Trio Giovani, Yogyakarta, 22 May 2016). As Hanung Bramantyo, Joko Anwar and Agus Santoso put, there is no single door in managing permits, so that social costs must be paid high enough for one shot. Agus gave an example, when filming on Jalan Kepodang or Chicken Market, according to data from the local Kelurahan office, only 20 traders paid the retribution, but when used for filming it could reach 120 people who came to ask for compensation, and the local government could not facilitate this problem.

\subsection{Strengths and Weaknesses of a film City}

Films produced in Kota Lama Area can be special themed films, and are colossal in nature. This shows that Kota Lama has a special potential as a center for film production. Yet, behind this great potential, several problems are related to the status of Kota Lama of Semarang as a cultural heritage area. (1) The condition of some buildings is not maintained. On the one hand, this is very dangerous and deserves to be saved, but on the other hand it visually meets the visual aesthetic needs for filmmaking. (2) The behavior standards of filmmakers for old buildings are the location of filmmaking. It is undeniable that filmmaking in Kota Lama bring forth various impacts. The placement of heavy production equipment, high-strength lighting to mass productivity needs to be examined more deeply whether or not it has a significant effect on the threat of building as a location for the film production. In addition to technical issues, the low level of understanding of film production crews in terms of knowledge of special treatment of old buildings can also have its own impact. (3) The absence of regulation, the obstacle experienced by filmmakers in Kota Lama of Semarang is the absence of rules that can guide makers in the film production in that location. Initially, the absence of regulation gives rise to a large visual roaming space for filmmakers to respond visually to Kota Lama, but the absence of current regulations is complicated as well. (4) Regional spatial design is set to overlap development policies that still threaten the authenticity of the region, having the potential to damage the visual aesthetic space. (5) The lack of public facilities is a separate problem. Some of the public facilities in question include adequate parking locations and other supporting facilities such as toilets, grocery stores and places of worship.

\section{Conclussion}

Kota Lama area of Semarang has a very distinctive visual potential, that is, an attraction for filmmakers in Indonesia to produce their films in that location. So far four clusters in Kota Lama of Semarang often become the location of film production, namely the Branjagan cluster, Kepodang Cluster, Blenduk Church Cluster, and Berok Bridge Cluster. In addition to the four clusters, several other places outside Kota Lama also exist as the location for making films as a buffer for the location of Kota Lama, namely Lawangsewu, Layur village, Chinatown, Karangpanas, Tinjomoyo and several other places. In addition to these locations, 
in Kota Lama, there are still places that have interesting visual potentials that have not been exploited, such as the Mpu tantular corridor, the Semarang Gallery corridor, Merak Corridor and several other corridors. The untouched corridors still have certain weaknesses that make film production unable to touch the corridor, including social problems and location productivity.

The visual superiority in the city of Semarang is also supported by non-technical factors that enable Semarang to become a national film production center, which has been dominated by Jakarta. These factors include easy access from Jakarta as the center of the film industry, as well as Solo and Yogyakarta that supply a lot of creative HR, putting Semarang as a city that has a strategic position in the film industry. In addition to the availability of sufficient accommodation facilities, filming locations are diverse, compact, and relatively free of traffic jams resulting in separate points to determine the location of film production in Semarang.

Moreover, to maximize the role of Kota Lama area as a center for film production in Indonesia, it is necessary to refine the problem maps, which include regulations and licensing, support for technical production of films, public support facilities, warehousing as storage workshops, and making artistic sets. Regulation becomes an important point, considering Kota Lama area is a cultural heritage that is obliged to get special treatment in terms of its utilization.

Acknowledgment. I would like to thank the research team and the publisher. This text is dedicated to the team of National Film Institute, ISI Surakarta, Indonesian Institute of Health, Padang Panjang Institute of Indonesian Arts and Culture, and Universitas Sarjanawiyata Tamansiswa Yogyakarta that has worked intensely to complete this research.

\section{References}

[1] W. Martokusumo, "Kota (Pusaka) Sebagai Living Museum."

[2] Murtomo, “Arsitektur Kolonial Kota Lama Semarang,” J. Enclos., vol. 7, 2008.

[3] Sukawi, "Mencari Potensi Wisata Kota Lama," vol. 7, 2008.

[4] Purwanto. MLF, "Kota Kolonial Lama Semarang (Tinjauan Umum Sejarah Perkembangan Arsitektur Kota)," J. Dimens. Tek. Arsit., vol. 33, 2005.

[5] LoBorto. Vincent, The Filmmakers Guide to Production Design. New York: Alworth press, 2002.

[6] B. Clave, Film Production Management, 2nd Editio. London: Focal Press., 2000.

[7] B. H. Bungin, Penelitian Kualitatif: Komunikasi, Ekonomi, Kebijakan Publik, dan Ilmu social. Jakarta: Kencana Prenama Media Group, 2007. 